\title{
Tetrandrine Induces Apoptosis in Human Nasopharyngeal Carcinoma NPC-TW 039 Cells by Endoplasmic Reticulum Stress and $\mathrm{Ca}^{2+} /$ Calpain Pathways
}

\author{
KUO-CHING LIU ${ }^{1}$, YA-JING LIN ${ }^{2}$, YUNG-TING HSIAO ${ }^{2}$, MENG-LIANG LIN ${ }^{1}$, \\ JIUN-LONG YANG ${ }^{3}$, YI-PING HUANG ${ }^{4}$, YUNG-LIN CHU ${ }^{*}$ and JING-GUNG CHUNG ${ }^{2,6^{*}}$ \\ ${ }^{1}$ Department of Medical Laboratory Science and Biotechnology, \\ China Medical University, Taichung, Taiwan, R.O.C.; \\ ${ }^{2}$ Department of Biological Science and Technology, China Medical University, Taichung, Taiwan, R.O.C.,; \\ ${ }^{3}$ Department of Chinese Pharmaceutical Sciences and Chinese Medicine Resources, \\ China Medical University, Taichung, Taiwan, R.O.C.; \\ ${ }^{4}$ Department of Physiology, China Medical University, Taichung, Taiwan, R.O.C.; \\ 5 International Master's Degree Program in Food Science, International College, \\ National Pingtung University of Science and Technology, Pingtung, Taiwan, R.O.C.; \\ ${ }^{6}$ Department of Biotechnology, Asia University, Taichung, Taiwan, R.O.C.
}

\begin{abstract}
Tetrandrine is an alkaloid extracted from a traditional China medicine plant, and is considered part of food therapy as well. In addition, it has been widely reported to induce apoptotic cell death in many human cancer cells. However, the mechanism of Tetrandrine on human nasopharyngeal carcinoma cells (NPC) is still questioned. In our study, we examined whether Tetrandrine can induce apoptosis of NPC-TW 039 cells. We found that cell morphology was changed after treatment with different concentrations of Tetrandrine. Further, we indicated that the NPC-TW 039 cells viability decreased in a Tetrandrine dosedependent manner. We also found that tetrandrine induced cell cycle arrest in $G_{0} / G_{1}$ phase. Tetrandrine induced DNA condensation by DAPI staining as well. In addition, we
\end{abstract}

*These Authors contributed equally to this work.

Correspondence to: Professor Jing-Gung Chung, Department of Biological Science and Technology, China Medical University, No 91, Hsueh-Shih Road, Taichung 404, Taiwan. Tel: +886 422053366 , ext. 8000, Fax: +886 4 22053764, e-mail: jgchung@mail.cmu.edu.tw; Assistant Professor Yung-Lin Chu, International Master's Degree Program in Food Science, International College, National Pingtung University of Science and Technology, Pingtung 912, Taiwan. Tel: +886 8 7703202, ext. 6411, Fax: +886 8 7740290, e-mail: pig9104412003@hotmail.com

Key Words: Tetrandrine, apoptosis, endoplasmic reticulum stress, $\mathrm{Ca}^{2+} /$ Calpain pathways, human nasopharyngeal carcinoma NPCTW 039 cells. found that Tetrandrine induced $\mathrm{Ca}^{2+}$ release in the cytosol. At the same time, endoplasmic reticulum (ER) stress occurred. Then we used western blotting to examine the protein expression which is associated with mitochondriamediated apoptotic pathways and caspase-dependent pathways. To further examine whether $\mathrm{Ca}^{2+}$ was released or not with Tetrandrine induced-apoptosis, we used the chelator of $\mathrm{Ca}^{2+}$ and showed that cell viability increased. At the same time, caspase-3 expression was decreased. Furthermore, confocal microscopy examination revealed that Tetrandrine induced expression of ER stress-related proteins GADD153 and GRP78. Our results indicate that Tetrandrine induces apoptosis through calcium-mediated ER stress and caspase pathway in NPC-TW 039 cells. In conclusion, Tetrandrine may could be used for treatment of human nasopharyngeal carcinoma in future.

Nasopharyngeal carcinoma is found with the highest prevalence in China and South East Asia. There are many types of nasopharyngeal carcinomas, such as non-keratinising carcinoma differentiated, keratinising squamous cell carcinoma and basaloid squamous cell carcinoma (1). In addition, it can migrate into lymph or other organs, especially the brain. The traditional treatment of nasopharyngeal carcinoma such as radiation and chemical therapy could damage and generate some irreversible side-effects in the brain. Therefore, the main focus of this study was to find an alternative treatment, and Tetrandrine was the main focus in this study.

Tetrandrine could be extracted by Stephania tetrandra, and is one of bis-benzylisoquinoline alkaloids which have 
anti-inflammatory and immune inhibitory abilities (2). There are lots of studies showing that Tetrandrine is an effective drug for immune diseases, inflammation and cardiovascular disease (3). In addition, Tetrandrine is useful in the treatment of lung silicosis, liver cirrhosis, and rheumatoid arthritis and has also been shown to inhibit entry of ebola virus into host cells in vitro $(4,5)$.

Cancer cells have sustained proliferative signalling resulting in the stimulation of cells' own growth, resistance of cell death or apoptosis, escape from growth suppressors and also have the ability to metastasize (6). However, apoptosis leads to cell morphology changes and deathincluding blebbing, cell shrinkage, chromatin condensation, DNA fragmentation, and global mRNA decay (7). Moreover, the cell signaling pathway of apoptotic cell death contains extrinsic and intrinsic signaling pathways, however, based on involved protein and organelles, it also can be classified into caspase-dependent, mitochondria-dependent and ER stress-related pathway (8-10). Therefore, the goal of this study was to identify the mechanism of apoptosis induction in nasopharyngeal carcinoma cells.

The relationship between calcium and cell death plays a key role in this study. Calcium associated signaling have been recognized to be a mediator of cell energy demand and a trigger to cell death (11). Calcium is not only related with mitochondria function and it is also involved endoplasmic reticulum maintain function. For example, mitochondria control energy and health in higher eukaryotes, and also calcium signals drive mitochondrial bioenergetic efficiency (12). Therefore, lots of human diseases are related with dysfunctional mitochondrial calcium uptake (13). In addition, endoplasmic reticulum bears some cellular stress like ROS attacking, and it also releases high concentrations of cytosolic calcium and unfolded protein response (UPR). Then highly $\left[\mathrm{Ca}^{2+}\right]_{\mathrm{ER}}$ and UPR would regulate apoptosis through the mitochondria and endoplasmic reticulum (14). In conclusion, the calcium concentration balance plays a key role in cell death.

However, there are no studies using Tetrandrine treatment of human nasopharyngeal carcinoma NPC-TW 039 cells. Although there is only one study which focuses on Tetrandrine with NPC-TW 076 cells (15). Both these cells are nasopharyngeal carcinoma cells, but have metabolic differences. For example, NPC-TW 076 cells are from a 36-year-old female Chinese patient living in Taiwan and NPC-TW 039 cells are contributed by a 64-year-old male patient in Taiwan. In addition, both of them have good metastatic ability but with different numbers of chromosomes (NPC-TW039 is 76 to 109; NPC-TW076 is 80 to 105), while morphology and doubling time are significantly different (16). Our study is the first to examine Tetrandrine treatment of nasopharyngeal cancer cells from elderly patients.

\section{Materials and Methods}

Chemicals and reagents. Tetrandrine was provided by China Medical University hospital, and Propidium iodide (PI), Annexin VFITC and Trypsin-EDTA were obtained from Sigma Chemical Co. (St. Louis, MO, USA). RPMI-1640 medium, fetal bovine serum (FBS), L-glutamine and penicillin-streptomycin were purchased from GIBCO ${ }^{\circledR} /$ Invitrogen Life Technologies (Carlsbad, California, USA). Fluo-3/AM, DiOC $6, \mathrm{H}_{2}$ DCF-DA were obtained by BD/Becton, Dickinson (BD Biosciences, San Jose, CA, USA). Primary antibodies against XIAP, Bcl-2, Bcl-x, Bad, Bax, Bid, cytochrome $c$, caspase-3, -8, -9, -12, Calpain-1, Calpain-2, Fas, FasL, AIF, Endo-G, GADD153, GRP-78 and chemical luciferase/ peroxidase conjugated secondary antibodies were purchased from Cell Signaling Technology, Inc. (Beverly, MA, USA).

Cell culture. Human nasopharyngeal carcinoma NPC-TW 039 cells were purchased from the Food Industry Research and Development Institute (Hsinchu, Taiwan). These cells were maintained in Dulbecco's Modified Eagle Medium (DMEM) medium with $2 \mathrm{mM}$ L-glutamine and supplemented with $10 \%$ FBS and $1 \%$ penicillinstreptomycin (100 Units/ml penicillin and $100 \mu \mathrm{g} / \mathrm{ml}$ streptomycin) and were incubated at $37^{\circ} \mathrm{C}$ in a humidified atmosphere of $5 \% \mathrm{CO}_{2}$ and $95 \%$ air (17).

Examinations of cell's morphology and total viability. NPC-TW 039 cells $\left(2 \times 10^{5}\right.$ cells/well $)$ were plated into 12 -well plates, cultured with DMEM medium for $24 \mathrm{~h}$ and were then incubated with 0,4 , $6,8,10,12 \mu \mathrm{M}$ of Tetrandrine for $48 \mathrm{~h}$. Cells in each well were examined and photographed under contrast phase microscopy at X 200. Viable cells were re-suspended in PBS and then counted with PI $(5 \mu \mathrm{g} / \mathrm{ml})$ followed immediately by flow cytometry (BD Biosciences, FACS Calibur, San Jose, CA, USA) as previously described $(7,18)$.

4,6-diamidino-2-phenylindole dihydrochloride staining for apoptotic cells. NPC-TW 039 cells $\left(2 \times 10^{5}\right.$ cells/well) were cultured in 12 -well plates with DMEM medium for $24 \mathrm{~h}$ and then incubated with 0,4 , 6,8 or $10 \mu \mathrm{M}$ of Tetrandrine for $48 \mathrm{~h}$. Cells were fixed with $3.7 \%$ paraformaldehyde (v/v) in PBS for $15 \mathrm{~min}$, permeabilized with $0.1 \%$ Triton $\mathrm{X}-100$ in PBS for 5 min and nuclei were stained with $2 \mu \mathrm{g} / \mathrm{ml}$ of 4',6-diamidino-2-phenylindole dihydrochloride (DAPI) for $30 \mathrm{~min}$. All samples were examined and photographed using a fluorescence microscope at X200 as described previously (19).

Cell cycle analysis. NPC-TW 039 cells $\left(2 \times 10^{5}\right.$ cells/well $)$ were maintained in 12-well plates with DMEM medium for $24 \mathrm{~h}$ and were then incubated with $0,4,6,8$ or $10 \mu \mathrm{M}$ of Tetrandrine for 48 h. At the end of incubation, cells were isolated and stained with PI and analyzed by flow cytometry as described previously (20) and the distribution of cells in each cell cycle phase, sub- $G_{1}, G_{0} / G_{1}, S$ and $\mathrm{G}_{2} / \mathrm{M}$, was determined.

Annexin V/PI staining for apoptotic cell death. Apoptotic cell death was measured using the Annexin V-FITC apoptosis detection kit as described previously (21). Briefly, NPC-TW 039 cells $\left(2 \times 10^{5}\right.$ cells $/ \mathrm{ml}$ ) grown in 12-well culture plates were treated with $0,4,6$, 8,10 or $12 \mu \mathrm{M}$ of Tetrandrine for $48 \mathrm{~h}$. After incubation, cells were collected and resuspended in Annexin $\mathrm{V}$ binding buffer, and incubated with Annexin V-FITC/PI in the dark for 15 min according 
to the manufacturer's instruction (22). In each experiment, 10,000 cells were analyzed using BD FACS (BD Biosciences, San Jose, CA, USA). Experiments were performed in triplicate.

Measurement of reactive oxygen species (ROS), intracellular $\mathrm{Ca}^{2+}$ and mitochondrial membrane potential $\left(\Delta \Psi_{m}\right)$. Measurement of ROS, $\mathrm{Ca}^{2+}$ and $\Delta \Psi_{m}$ in NPC-TW 039 cells was performed by flow cytometry after exposure to Tetrandrine $(7,23)$. Briefly, NPC-TW 039 cells $\left(2 \times 10^{5}\right.$ cells/well $)$ were maintained in 12 -well plates and were treated with $8 \mu \mathrm{M}$ of Tetrandrine for $0,6,12,24$ or $48 \mathrm{~h}$. After incubation, cells were harvested and re-suspended with $500 \mu \mathrm{l}$ of DCFH-DA $(10 \mu \mathrm{M})$ for ROS $\left(\mathrm{H}_{2} \mathrm{O}_{2}\right)$ measurement, $500 \mu \mathrm{l}$ of DiOC6 (4 $\mu \mathrm{mol} / \mathrm{l})$ for the levels of $\Delta \Psi_{m}$ measurement, or $500 \mu \mathrm{l}$ of Fluo-3/AM $(2.5 \mu \mathrm{g} / \mathrm{ml})$ for Calcium measurement and all samples were kept in the dark for $30 \mathrm{~min}$. After incubation, all samples were analyzed by flow cytometry as described previously $(18,24,25)$.

Caspase-3, caspase-8 and caspase- 9 activities assay. The activities of caspase- $8,-9$ and -3 of NPC-TW 039 cells after treatment with Tetrandrine were measured by flow cytometry (26). NPC-TW 039 cells $\left(2 \times 10^{5}\right.$ cells/well $)$ were incubated with various concentrations of Tetrandrine for $48 \mathrm{~h}$ and then samples were collected, washed and re-suspended in $25 \mu \mathrm{l}$ of $10 \mu \mathrm{M}$ caspase- $8,-9$ and -3 substrates (CaspaLux8-L1D2,- CaspaLux 9-M1D2 and PhiPhiLux-G1D2) (OncoImmunin, Inc. Gaithersburg, MD, USA) before incubation at $37^{\circ} \mathrm{C}$ for $60 \mathrm{~min}$. After incubation, cells were washed with PBS and were immediately analyzed by flow cytometry for activities of caspase- $8,-9$ and -3 as described previously (27).

Western blotting analysis. NPC-TW 039 cells $\left(1 \times 10^{6}\right.$ cells/dish $)$ were plated in $10 \mathrm{~cm}$ dish for $24 \mathrm{~h}$ and then treated with $8 \mu \mathrm{M}$ of Tetrandrine for $0,6,12,24$ or $48 \mathrm{~h}$. Cells were collected and lysed in lysis buffer (10 mM Tris- $\mathrm{HCl}$ (pH7.4), $150 \mathrm{mM} \mathrm{NaCl}, 1 \mathrm{mM}$ EGTA, $0.3 \mathrm{mM}$ PMSF, $0.2 \mathrm{mM}$ sodium orthovanadate, $0.1 \% \mathrm{SDS}$ $1 \mathrm{mM}$ EDTA, $1 \% \mathrm{NP}-40,10 \mathrm{mg} / \mathrm{mL}$ leupeptin, and $10 \mathrm{mg} / \mathrm{mL}$ aprotinin). All samples were incubated on ice for $15 \mathrm{~min}$ and the supernatant was collected after centrifugation at $15,000 \times g$ for 20 $\min$. The total protein from each sample was determined by the Bio-Rad protein assay kit (Hercules, California, USA) as described previously (20). Approximately $30 \mu \mathrm{g}$ of total protein from each sample was loaded to each well and SDS-PAGE analysis was performed according to previous studies and then transferred onto polyvinylidene difluoride (PVDF) membranes. Membranes were blocked with 5\% non-fat dried milk in PBST. The membranes were immunoblotted with specific primary antibodies followed by the appropriate horseradish peroxidaselinked secondary antibody. Detection of each band was performed using Chemiluminescence $(28,29)$.

BAPTA-Calcium Chelation. The $10 \mu \mathrm{l}$ of $0.5 \mu \mathrm{M}$ BAPTA $(1,2-$ Bis(2-Aminophenoxy)ethane- $\mathrm{N}, \mathrm{N}, \mathrm{N}^{\prime}, \mathrm{N}^{\prime}$-tetra acetic acid) was placed in NPC-TW 039 cells $\left(2 \times 10^{5}\right.$ cells/well $)$ at 12 -well plate with DMEM medium for $6 \mathrm{~h}$ and then were treated with $8 \mu \mathrm{M}$ of Tetrandrine for $48 \mathrm{~h}$. After incubation, viability, intracellular $\mathrm{Ca}^{2+}$ and caspase- $9,-3$ activities were analyzed by flow cytometric assay as described previously (18).

Protein fluorescence expression detection. Protein expression of GADD153 and GRP78 were measured by an immunostaining Method. NPC-TW 039 cells were placed on Polysine microscope adhesion slides (Cell-line, Thermo), pretreated with $0.5 \mu \mathrm{M}$ BAPTA for $6 \mathrm{~h}$ and then were treated with $8 \mu \mathrm{M}$ Tetrandrine. At $24 \mathrm{~h}$, cells were fixed in $4 \%$ paraformaldehyde/PBS and stained with antiGADD153 and GRP78 (Cell Signaling) according to the dilution of the data sheet. The protein expression of GADD153 and GRP78 were acquired on a Leica TCS SP5 II confocal laser scanning microscope.

Statistical analysis. All data were presented as mean \pm standard deviation (SD) from triplicate experiments. Statistical significant differences between the Tetrandrine treated and -untreated (control) groups were analyzed by Student's $t$-test. The levels of statistical significance were considered when the $p$-value was less than 0.05 .

\section{Results}

Tetrandrine induced cell morphological changes and decreased the percentage of viable NPC-TW 039 cells. NPC-TW 039 cells were treated with $0,4,6,8,10$ and 12 $\mu \mathrm{M}$ of Tetrandrine for $48 \mathrm{~h}$. Cells were examined for morphological changes by contrast-phase microscopy and measured for the total percentage of viable cells (Figures 1A and B). Results indicated that Tetrandrine induced cell morphological changes (Figure 1A) based on cell floating, debris and decreased number of viable cells (Figure 1B) accompanying the dead cells and these effects were dosedependent. Treatment with $8 \mu \mathrm{M}$ of Tetrandrine led to a $50 \%$ decrease of viable cells compared to the control group, thus, $8 \mu \mathrm{M}$ of Tetrandrine was selected for most of the further experiments.

Tetrandrine induced DNA condensation in NPC-TW 039 cells. NPC-TW 039 cells were treated with various doses $(4$, 6,8 and $10 \mu \mathrm{M}$ ) of Tetrandrine for $48 \mathrm{~h}$. As shown in Figure 2 , these assays demonstrated that Tetrandrine-induced DNA condensation as examined by DAPI staining (Figure 2A) when compared with the control sample. Also, quantitation of DNA condensation was examined by Image $\mathbf{J}$ software (Figure 2B) in NPC-TW 039 cells. Taken together, we concluded that Tetrandrine decreased the percentage of viable NPC-TW 039 cells through DNA condensation and induction of apoptotic death.

Tetrandrine induced apoptosis in NPC-TW 039 cells. To further confirm whether Tetrandrine decreased total cell numbers through the induction of apoptosis of NPC-TW 039 cells, cell cycle and Annexin V/PI double staining assay were used to measure the percentage of apoptotic cell death and the results are shown in Figure 3. Figure 3A demonstrates that Tetrandrine could increase cell accumulation in sub- $\mathrm{G}_{1}$ and $\mathrm{G}_{0} / \mathrm{G}_{1}$ phases. Moreover, Figure $3 \mathrm{~B}$ and $\mathrm{C}$ show that Tetrandrine induced early and late apoptotic cells at $15-50 \%$ following $48 \mathrm{~h}$ treatment in NPCTW 039 cells. We concluded that Tetrandrine could cause cell cycle arrest in $\mathrm{G}_{0} / \mathrm{G}_{1}$ phase and early and late apoptosis in NPC-TW 039 cells. 
(A)

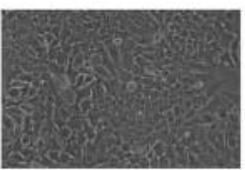

Control (X 200)

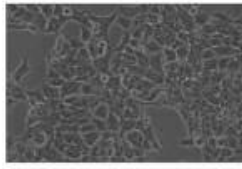

$4 \mu \mathrm{M}$ (X 200)

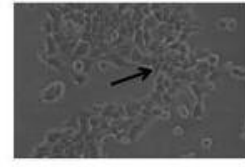

$6 \mu \mathrm{M}(\mathrm{X} 200)$

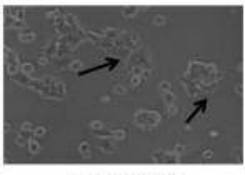

$8 \mu \mathrm{M}$ (X 200)

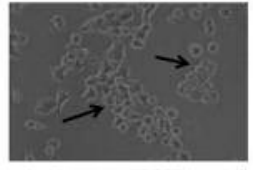

$10 \mu M(X 200)$
(B)

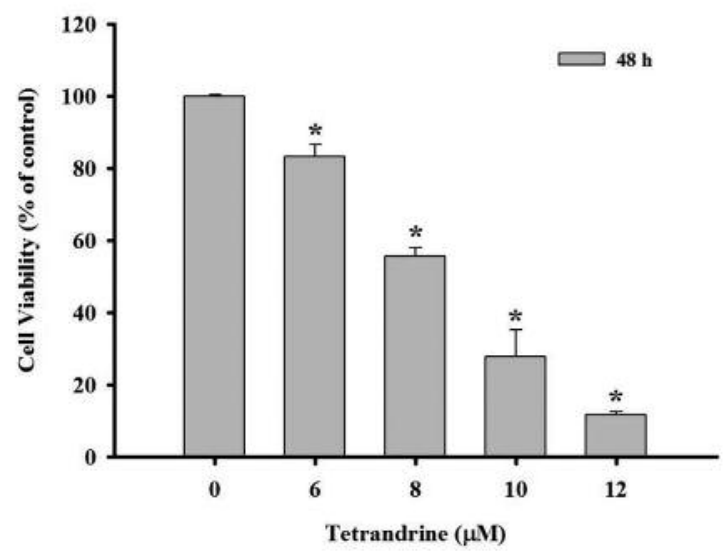

Figure 1. Tetrandrine induced cell morphological changes and decreased the viability in human nasopharyngeal carcinoma NPC-TW 039 cells. Cells $\left(2 \times 10^{5}\right.$ cells/well $)$ were plated in a 12-well plate for $24 \mathrm{~h}$ and were incubated with 0, 4, 6, 8, 10 or $12 \mu \mathrm{M}$ of Tetrandrine for 48 h. Cells were examined and photographed under contrast phase microscope (A) or were assayed for percentages of viable cells (B) as described in Material and Methods. Each point is mean \pm S.D. of three experiments. *p<0.05. Significantly different from tetrandrine-treated and control cells.

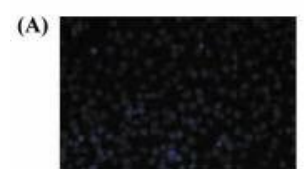

Control (X 200)

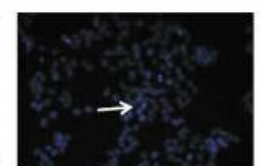

$4 \mu \mathrm{M}$ (X 200)

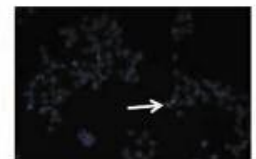

$6 \mu \mathrm{M}(\mathrm{X} \mathrm{200)}$

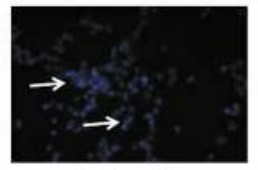

$8 \mu \mathrm{M}(\mathrm{X} 200)$

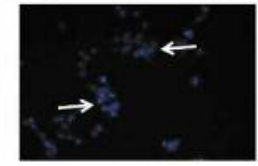

$10 \mu \mathrm{M}$ ( X 200)
(B)

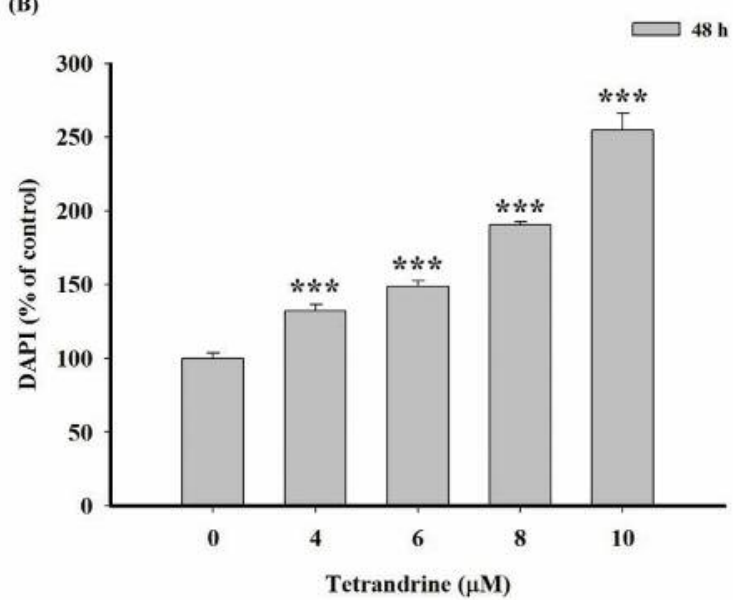

Figure 2. Tetrandrine induced DNA condensation in human nasopharyngeal carcinoma NPC-TW 039 cells. Cells $\left(2 \times 10^{5}\right.$ cells/well) were placed in a 12-well plate for $24 \mathrm{~h}$ and were incubated with 0, 4, 6, 8 or $10 \mu \mathrm{M}$ of Tetrandrine for $48 \mathrm{~h}$. Cells were examined and photographed under fluorescent light microscope (A) or were assayed for percentages of DNA damaged cells (B) as described in Material and Methods. Each photo is mean \pm S.D. of three experiments. $* * * p<0.001$. Significantly different from Tetrandrine-treated and control cells.

Tetrandrine induced reactive oxygen species and $\mathrm{Ca}^{2+}$ productions and the levels of mitochondrial membrane potential $\left(\Delta \Psi_{m}\right)$ in NPC-TW 039 cells. In order to further clarify whether Tetrandrine-induced apoptotic cell death involved the production of ROS and $\mathrm{Ca}^{2+}$ or mitochondrial dysfunction of NPC-TW 039 cells, cells were treated with 8 $\mu \mathrm{M}$ of Tetrandrine for $0,3,6,9,12,24$ or $48 \mathrm{~h}$ and analyzed for ROS, $\mathrm{Ca}^{2+}$ and levels of $\Delta \Psi_{\mathrm{m}}$ by flow cytometric assay. Results are shown in Figure 4. Figures 4A and B show that tetrandrine significantly increased ROS production at 3-24 h treatment and $\mathrm{Ca}^{2+}$ from 6-48 h treatment. Figure $4 \mathrm{C}$ indicated that tetrandrine increased the levels of mitochondrial membrane potential $\left(\Delta \Psi_{\mathrm{m}}\right)$ from $12-48 \mathrm{~h}$ treatment.

Tetrandrine increased the activities of caspase-3, -8 and -9 in NPC-TW 039 cells. To further investigate whether or not Tetrandrine induced apoptotic cell death in NPC-TW 039 cells via the activation of caspases, NPC-TW 039 cells were 
(A)

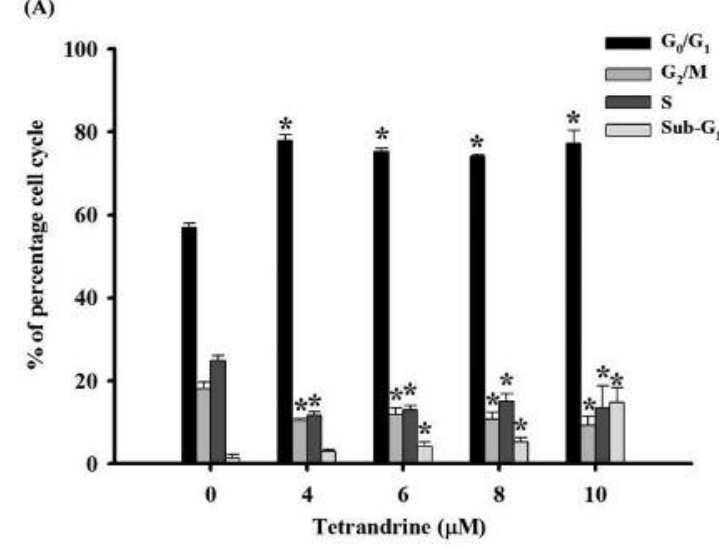

(B)

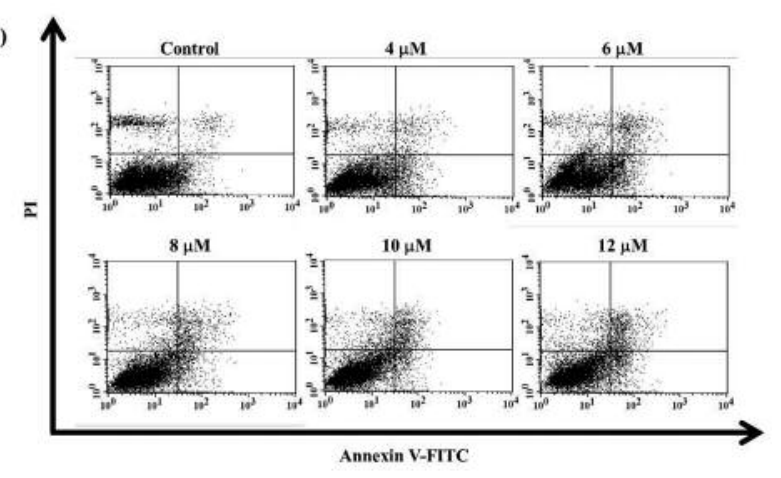

(C)

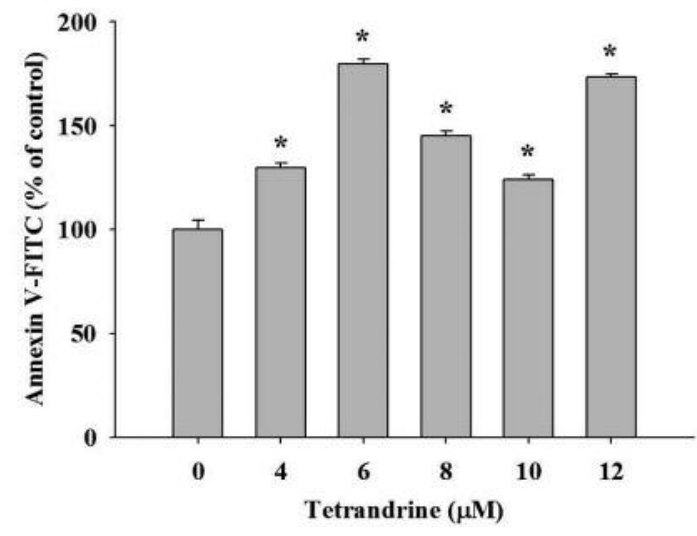

Figure 3. Tetrandrine induced apoptotic cell death in human nasopharyngeal cancer NPC-TW 039 cells. Cells $\left(2 \times 10^{5}\right.$ cells/well $)$ in 12-well culture plates were treated with $0,4,6,8,10$ or $12 \mu \mathrm{M}$ of Tetrandrine for $48 \mathrm{~h}$. Cells were collected and were resuspended in cellcycle buffer and Annexin $V$ binding buffer, followed by incubation with PI cell-cycle buffer (A) and Annexin V-FITC/PI (B) and were assayed for percentage of apoptotic cell death $(C)$ as described in Materials and Methods. ${ }^{*} p<0.05$. Significantly different from Tetrandrine-treated and control cells.
(A)

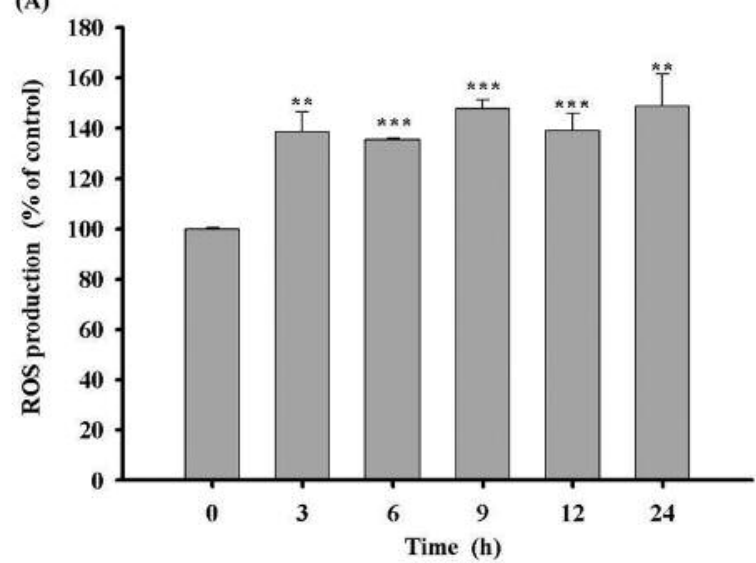

(B)

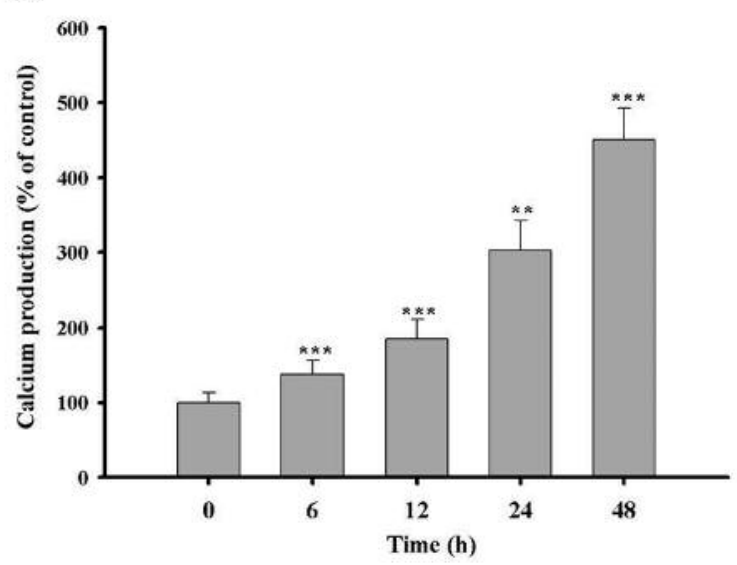

(C)

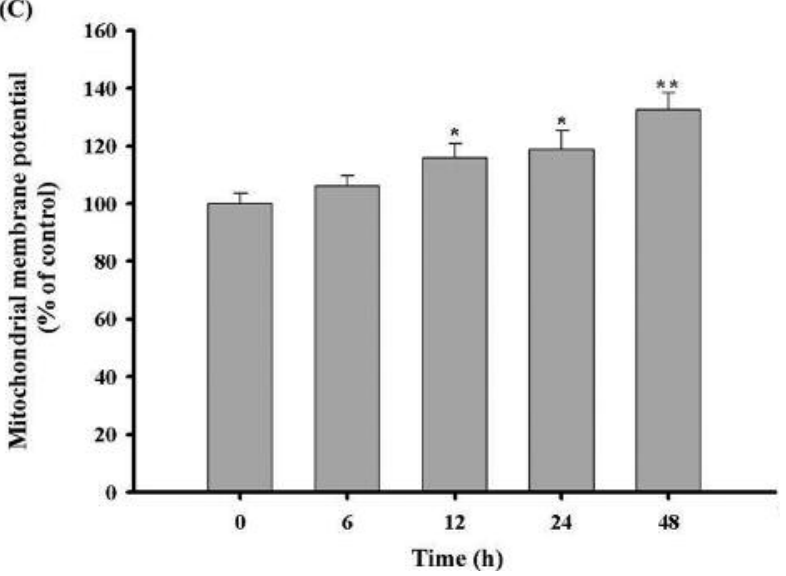

Figure 4. Tetrandrine induced reactive oxygen species and $\mathrm{Ca}^{2+}$ production and decreased the levels of mitochondrial membrane potential $\left(\Delta \Psi_{m}\right)$ in NPC-TW 039 cells. Cells $\left(2 \times 10^{5}\right.$ cells/well $)$ were treated with $8 \mu \mathrm{M}$ of Tetrandrine for 0, 6, 12, 24 or $48 \mathrm{~h}$. Cells were isolated and assayed for the production of $\operatorname{ROS}(A)$ and $\mathrm{Ca}^{2+}(B)$, and the levels of $\triangle \Psi m$ measurement $(C)$ as described in Materials and Methods. Data are mean \pm S.D. of three experiments. ${ }^{*} p<0.05$, ${ }^{*} p<0.01$ and $* * * p<0.001$. Significantly different from Tetrandrine-treated and control cells. 
treated with $0,4,6,8,10$ or $12 \mu \mathrm{M}$ of Tetrandrine for $48 \mathrm{~h}$ and cells were measured for the activities of caspase-8, -9 and -3 by flow cytometry (Figure 5A-C). Results indicated that Tetrandrine increased the activities of caspase- $8,-9$ and -3 in NPC-TW 039 cells.

Tetrandrine altered apoptosis associated protein expression in NPC-TW 039 cells. In order to further examine whether Tetrandrine-induced apoptosis of NPC-TW 039 cells involves the effects of apoptosis-associated proteins, NPCTW 039 cells were treated with Tetrandrine $(8 \mu \mathrm{M})$ for 0,6 , 12,24 and $48 \mathrm{~h}$ and then apoptosis associated proteins were measured and quantitated with Western blotting. Results are shown in Figure 6. Results demonstrated that Tetrandrine significantly decreased the expression of Bid (24-48 h) (Figure 6A) and cytochrome $\mathrm{c}$ at $24-48 \mathrm{~h}$ treatment (Figure 6B), pro-caspase-8 at 6-24 h treatment (Figure 6C), procaspase-9 at $12-48 \mathrm{~h}$ treatment (Figure $6 \mathrm{D}$ ). Tetrandrine increased Bcl-x, Bcl-2 and Bax at 6-48 h (Figure 6A) but only increased AIF and Endo G at $24 \mathrm{~h}$ treatment (Figure 6B), increased Fas, Fas-L, caspase- 8 and caspase- 3 at 6-48 $\mathrm{h}$ treatment (Figure 6C), and increased Calpain-1, Calpain2, caspase-12 and caspase-9 at 12-48 h treatment (Figure 6D) in NPC-TW 039 cells. These results indicated that Tetrandrine induced apoptosis of NPC-TW 039 cells through the cell surface receptor (Fas-L and Fas), and induced ER stress and caspase-dependent pathways.

Tetrandrine induced calcium-mediated cell death in NPC-TW 039 cells. In order to further investigate whether Tetrandrine induced calcium-mediated apoptotic cell death of NPC-TW 039 cells, we use BAPTA pre-treatment as calcium chelation to block calcium ion concentration released by endoplasmic reticulum stress. From Figure 7A, NPC-TW 039 cells was pre-treated $0.5 \mu \mathrm{M}$ BAPTA for $6 \mathrm{~h}$ and then co-treated with Tetrandrine at $48 \mathrm{~h}$. It clearly showed that BAPTA treatment alone did not damage cell viability but co-treatment of BAPTA with Tetrandrine significantly recovered cell viability compared with cells treated with Tetrandrine alone. Furthermore, Figure 7B shows that Tetrandrine treatment increased calcium release in the cytosol but co-treatment with BAPTA inhibited the calcium release from the endoplasmic reticulum. From Figure 8A and B, Tetrandrine treatment induced activation of caspase- 9 and -3 , and BAPTA co-treatment significantly inhibited the activation of caspase- 9 and -3 . These results indicate that Tetrandrine induced calcium-mediated apoptosis in NPC-TW 039 cells.

Tetrandrine induced endoplasmic reticulum (ER) stress in NPC-TW 039 cells. GRP78 and GADD153 proteins are the hallmarks of ER stress. As shown in Figures 9A and 9B, we used confocal microscopy to demonstrate protein expression of GRP78 and GADD153 by staining of NPC-TW 039 cells.
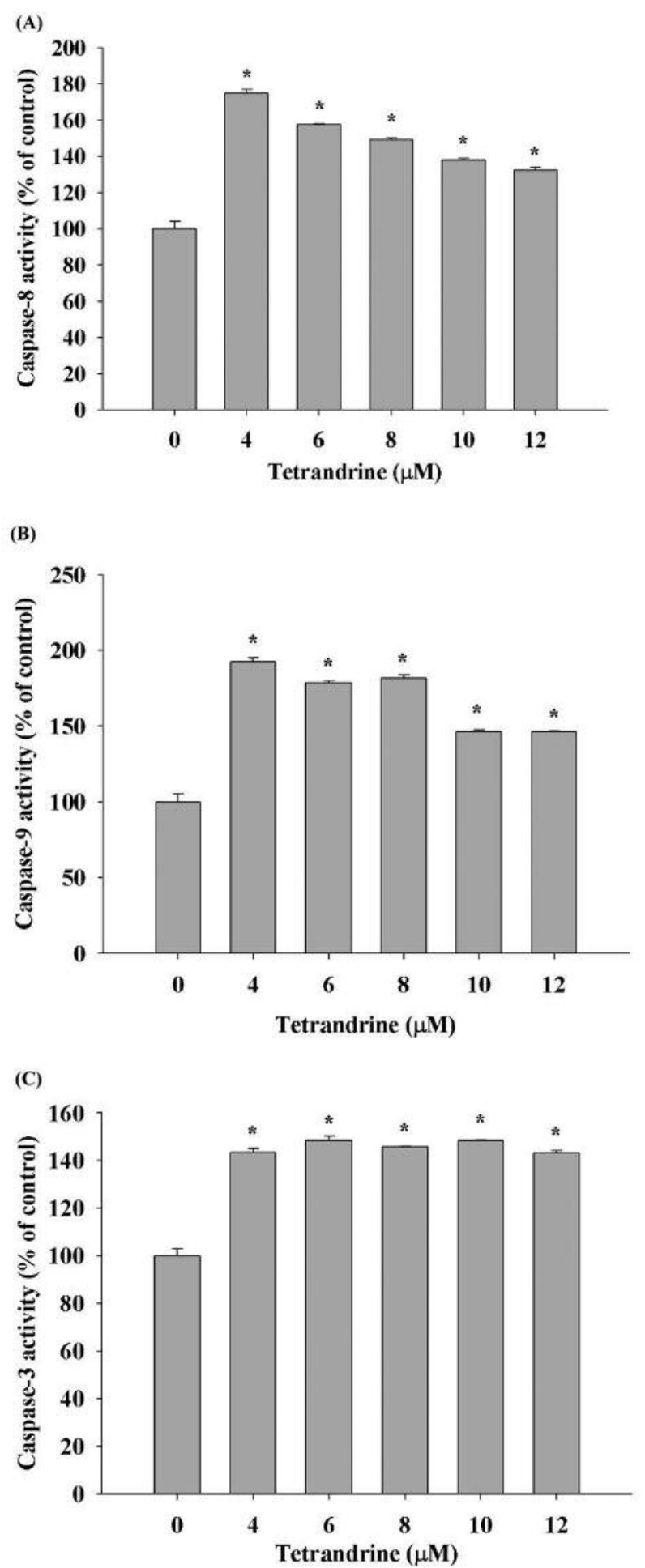

Figure 5. Tetrandrine induced caspase-3, -8 and -9 activities in NPCTW 039 cells. Cells were treated with or without Tetrandrine (4, 6, 8, 10 and $12 \mu \mathrm{M})$ before cells being harvested and activities of caspase- 8 (A), $-9(B)$ and -3 (C) were measured by flow cytometric assay as described in Materials and Methods. Data are mean \pm S.D. of three experiments. ${ }^{*} p<0.05$. Significantly different from Tetrandrine-treated and control cells. 
(A)

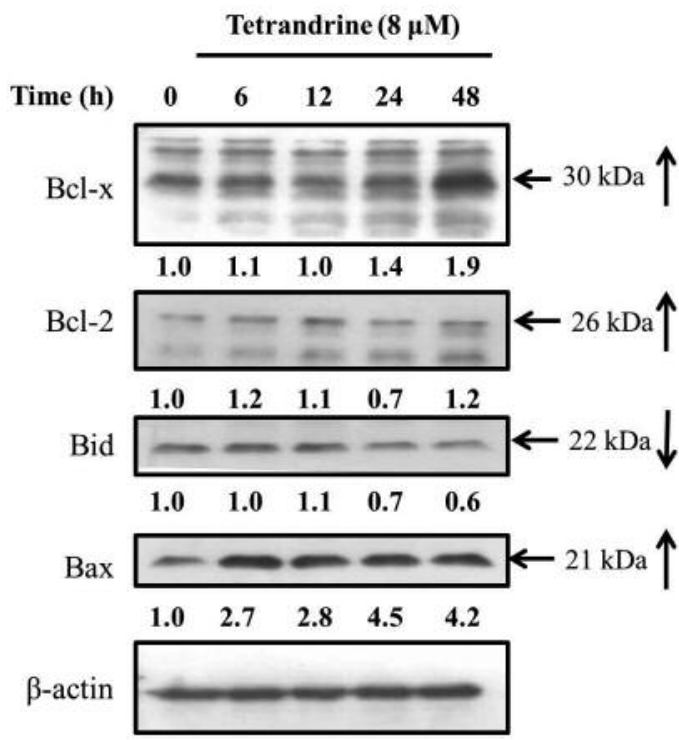

(C)

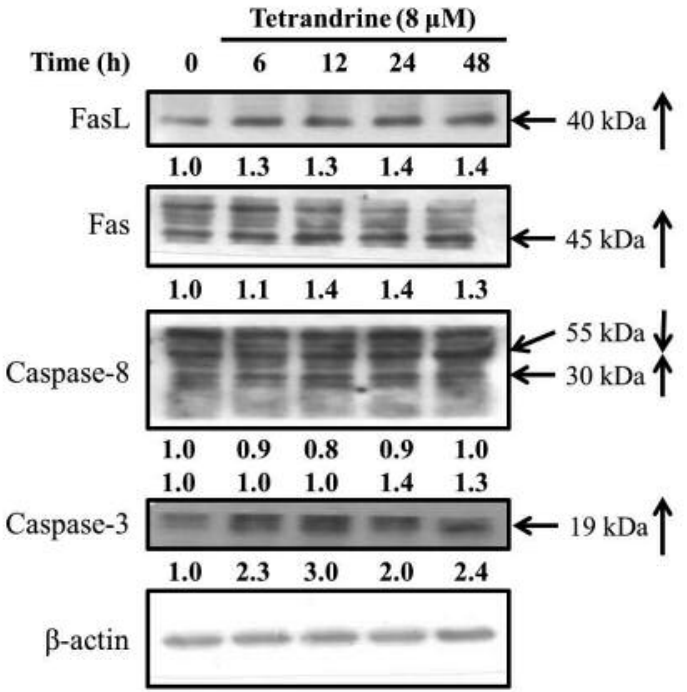

(B)

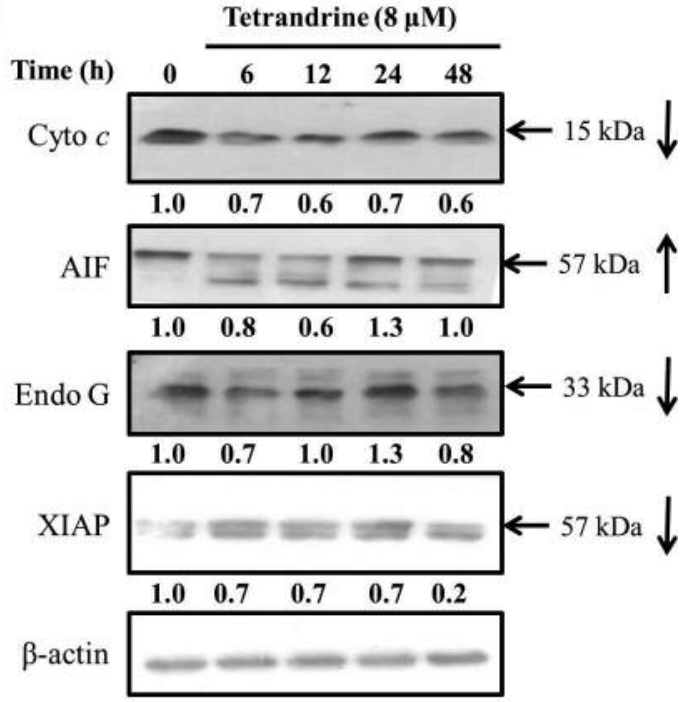

(D)

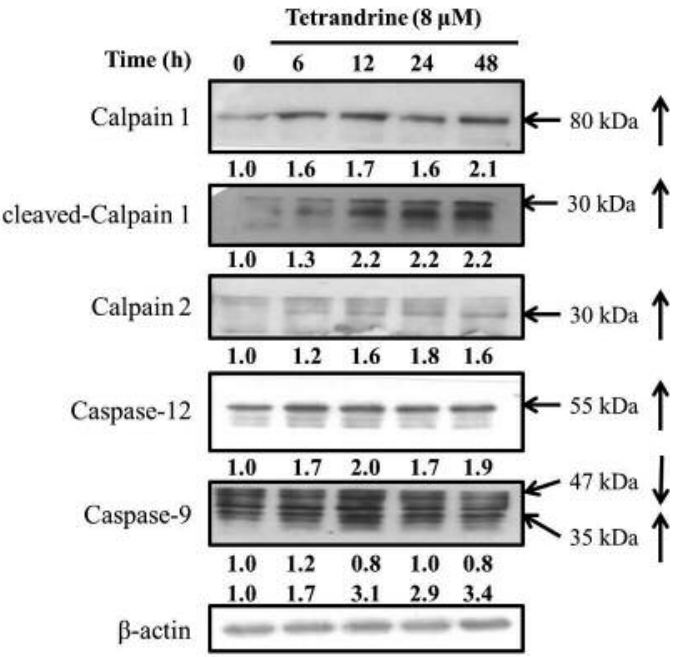

Figure 6. Tetrandrine affected the levels of associated proteins in apoptosis of NPC-TW 039 cells. Cells $\left(1 \times 10^{6}\right.$ cells/dish $)$ were treated with Tetrandrine $(8 \mu M)$ for 0, 6, 12, 24 or $48 \mathrm{~h}$ and then the total protein were measured and used for SDS page gel electrophoresis as described in Materials and Methods. The levels of Bax, Bid, Bcl-2, Bcl-x (A); cytochrome c, AIF, Endo G (B); Fas, Fas-L, caspase-3 and caspase-8 (C); Calpain-1, Calpain-2, caspase-9 and caspase-12(D).

Figure 9A shows NPC-TW 039 cells after Tetrandrine treatment for $24 \mathrm{~h}$ which increased the protein expression of GRP78. In addition, BAPTA co-treatment blocked the protein activation induced by Tetrandrine. Using the same treatment, the protein expression of GADD153 was induced by Tetrandrine, but inhibited by BAPTA co-treatment (Figure 9B). All data demonstrated that Tetrandrine induced calciummediated ER stress in NPC-TW 039 cells.

\section{Discussion}

Nasopharyngeal cancer is uncommon in the United States and other nations, but it is extremely common in southern regions of China, particularly in Guangdong, accounting for $18 \%$ of all cancers in China (30). In addition, it is also quite common in Taiwan. This could be due to the South East Asian diet which typically includes the consumption of salted vegetables, fish, and meat but also smoking. However, not only the 
(A)

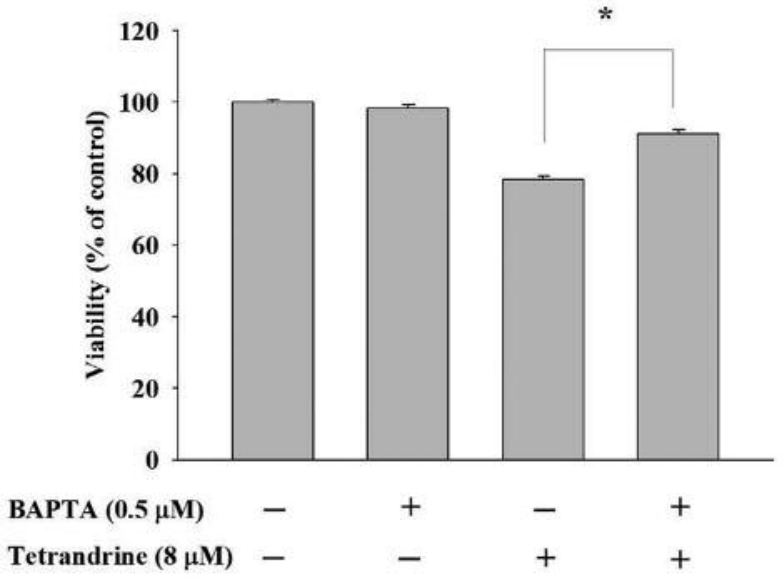

(B)

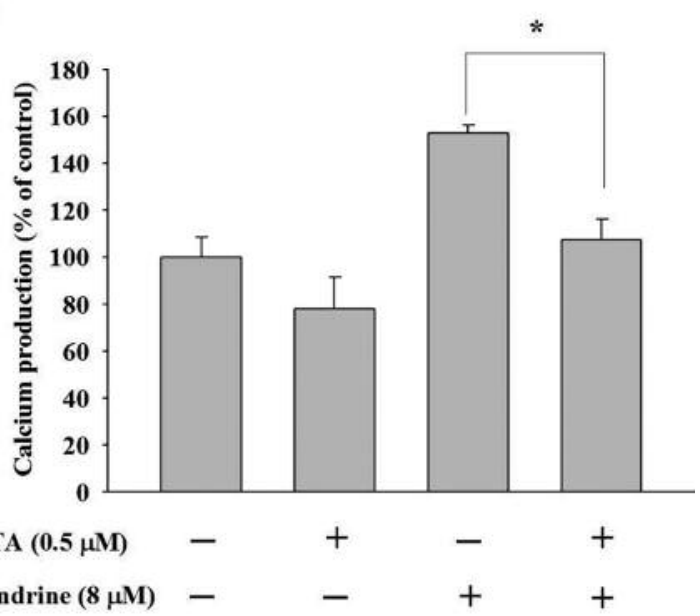

Figure 7. Co-treatment of BAPTA and Tetrandrine affected the cell viability and releasing of calcium in human nasopharyngeal cancer NPC-TW 039 cells. Cells $\left(2 \times 10^{5}\right.$ cells/well $)$ were treated with $0.5 \mu M$ BAPTA within 6 h before $8 \mu M$ of Tetrandrine for 48 h for viable cells determination (A) and by Fluo-3/AM for $\mathrm{Ca}^{2+}$ levels determination $(B)$ as described in Materials and Methods. Data represents mean \pm S.D. of three experiments. $* p<0.05$. Significant recovery from Tetrandrine co-treated with BAPTA and only Tetrandrine treating cells.

(A)

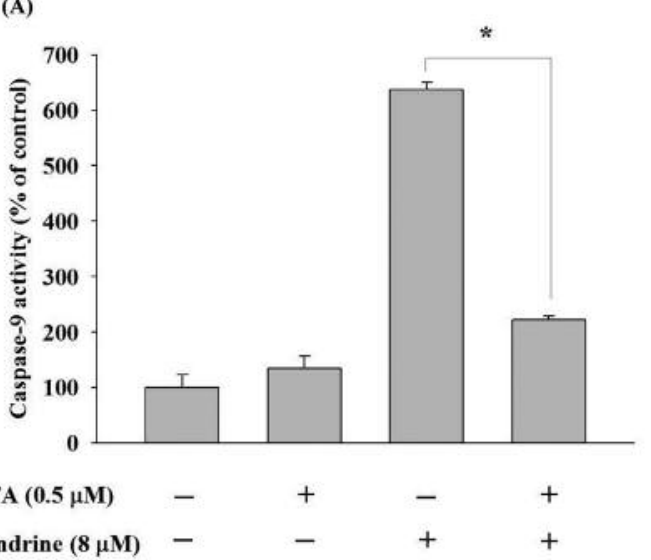

(B)

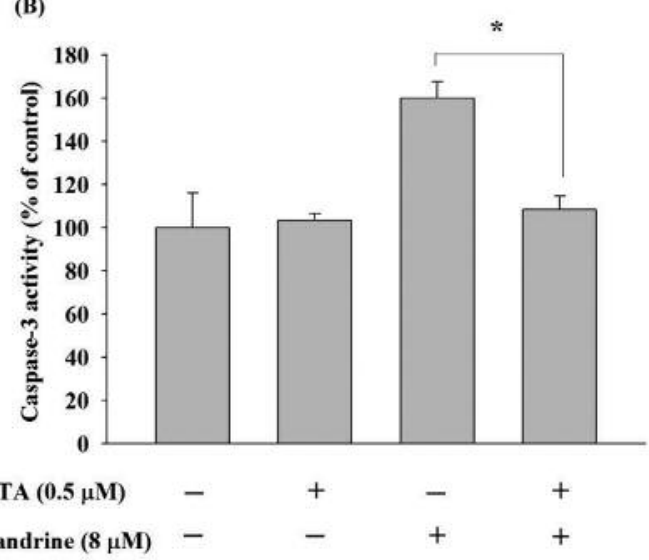

Figure 8. Co-treatment of BAPTA and Tetrandrine stimulated the activities of caspase-9 and -3 in human nasopharyngeal cancer NPC-TW 039 cells. Cells $\left(2 \times 10^{5}\right.$ cells/well) were treated with $0.5 \mu M$ BAPTA within 6 h before $8 \mu M$ of Tetrandrine for 48 hor caspase- 9 determination (A) and by caspase-3 determination (B) as described in Materials and Methods. Data represents mean \pm S.D. of three experiments. * $<<0.05$. Significant recovery from Tetrandrine co-treated with BAPTA and only Tetrandrine treating cells.

lifestyle but also genes could regulate nasopharyngeal cancer. For example, expression of human cytochrome P450 2E1 gene has been reported to be tightly connected with the progression of nasopharyngeal cancer (31). Therefore, although numerous studies have shown that Tetrandrine has biological activities including anti-cancer in vitro and in vivo, and was reported that regulates the gene and protein expression of mitochondria and inhibit the growth of gastric cancer BGC-823 cells (32). It has also been reported that it enhances radio-sensitivity through apoptosis in nasopharyngeal cancer CNE cells (33).
On the other hand, Tetrandrine exhibits an anticancer metastatic and antiangiogenic activities better than those of doxorubicin (34). These references show that Tetrandrine may play a potential role in cancer therapy. Furthermore, it was reported that Tetrandrine suppresses inflammation as well (35). However, there is still no available information to show the effect of Tetrandrine on cell death regulation in human Nasopharynx cancer cells, thus, in the present study, we investigated the cytotoxic effects of Tetrandrine on human nasopharyngeal cancer NPC-TW 039 cells in vitro. 

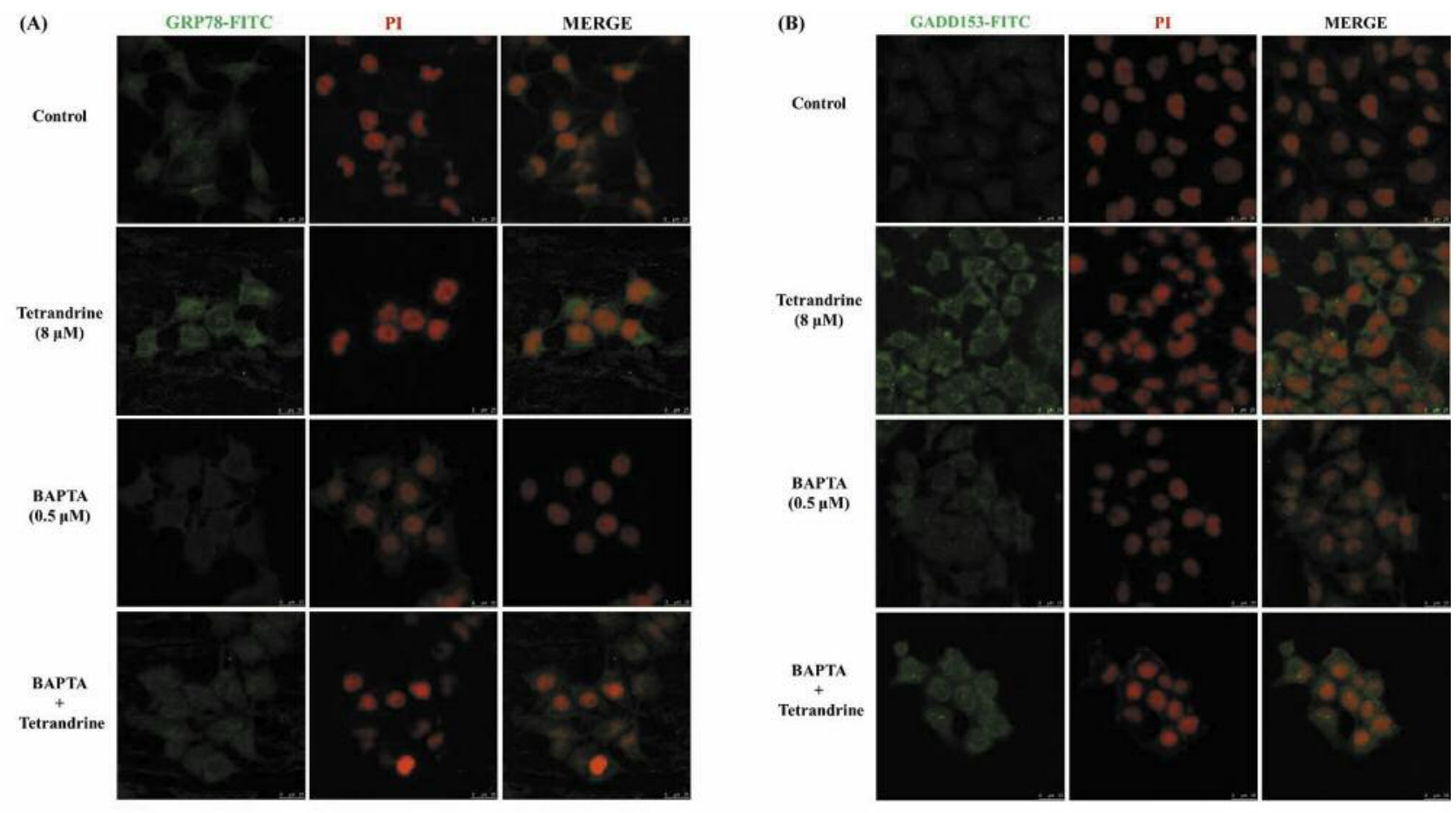

Figure 9. Co-treatment of BAPTA and Tetrandrine affected the protein fluorescence expressions of GRP78 and GADD153 in human nasopharyngeal cancer NPC-TW 039 cells. Cells $\left(2 \times 10^{5}\right.$ cells $/$ well $)$ were treated with $0.5 \mu M$ BAPTA within 6 h before $8 \mu M$ of Tetrandrine for 24 h for the protein expression of GRAP78 (A) and GADD153 (B) were acquired on a Leica TCS SP5 II confocal laser scanning microscope.

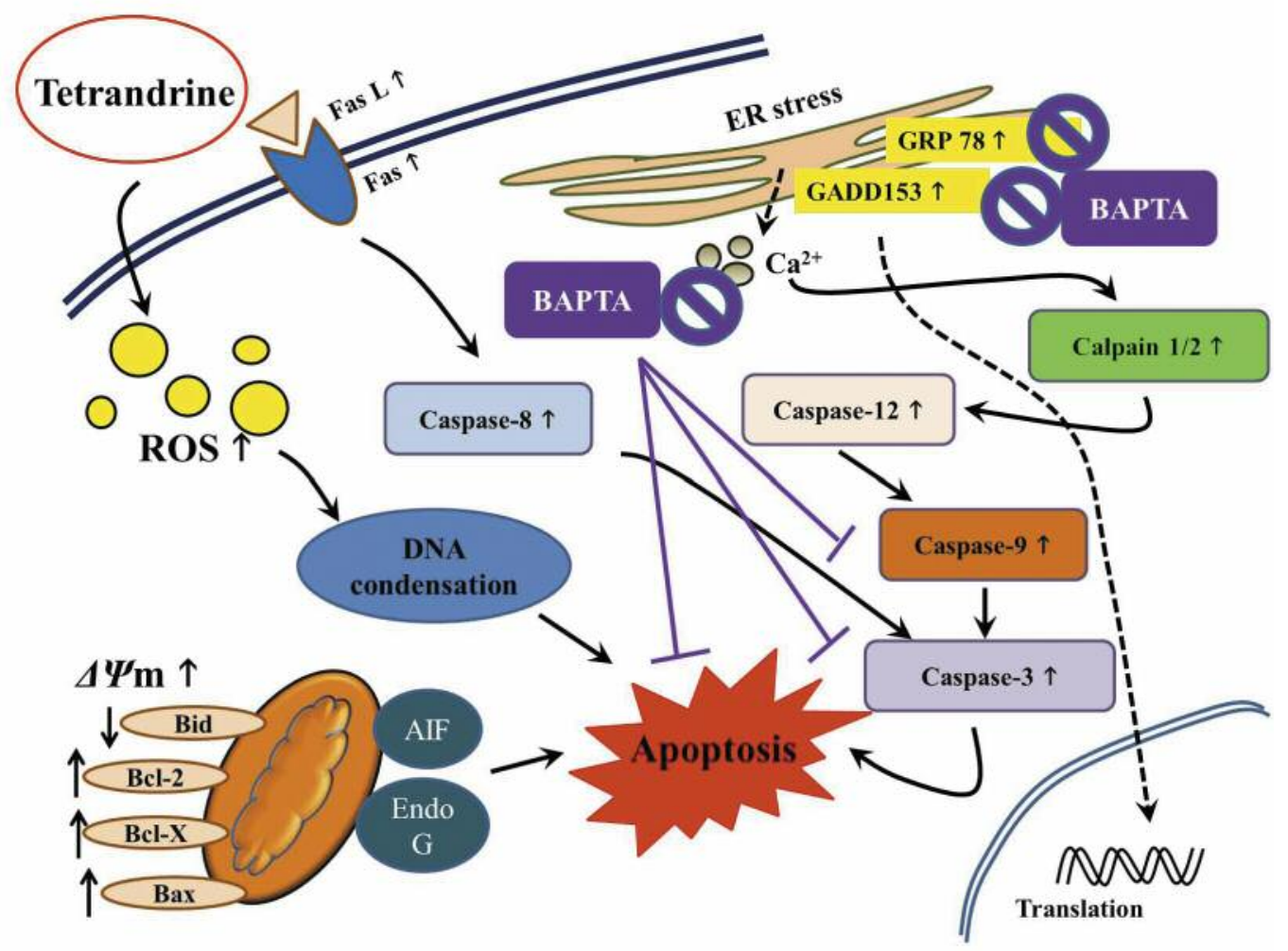

Figure 10. The possible mechanism of Tetrandrine treated on human nasopharyngeal cancer NPC-TW 039 cells. 
We found that Tetrandrine induced cell morphological changes (Figure 1A) and decreased the percentage of viable cells (Figure 1B); Tetrandrine induced DNA condensation (Figure 2) and apoptotic cell death (Figure 3); increased ROS levels, calcium ion release and increased the levels of $\Delta \Psi_{m}$ (Figure 4 A-C); increased the activities of caspase-8, -9 and -3 (Figure $5 \mathrm{~A}-\mathrm{C}$ ); increased expression of the mitochondria-related pathway proteins, Bcl-2 and Bcl-x (Figure 6A); increased the expression of the pro-apoptotic proteins such as Bax, AIF, Endo G (Figures 6A and B) and decreased cytochrome $c$ release (Figure 6B) that was associated with dysfunction of mitochondria and death through the cell surface receptor Fas and Fas-L (Figure 6C). Tetrandrine increased caspases-3, $-8,-9$ and -12 (Figures 6C and $D$ ) that were the markers of apoptosis. Tetrandrine increased Calpain-1 and -2 (Figure 6D) that were the marker of calcium-activated proteases which is related with ubiquitous enzymes.

Tetrandrine decreased cell number through the induction of apoptotic cell death in NPC-TW 039 cells that were measured by PI and Annexin V/PI double staining and analyzed by flow cytometry. It is well demonstrated that Annexin V/PI staining is very efficient for measuring and quantitating the percentage of apoptotic cell death $(26,36)$. We also found that Tetrandrine induces apoptotic cell death through ER stress in NPC-TW 039 cells based on ROS production (Figure 4A) and GADD153 and GRP78 that were the hallmarks of ER stress (Figure 9A and B). Our earlier studies also showed that Tetrandrine induced apoptosis through ROS production and mitochondriadependent cell death in human nasopharynx cancer NPCTW 076 cells (15). ROS production in cancer cells after exposure to anticancer agents, decreased mitochondria membrane potential $\left(\Delta \Psi_{m}\right)$ and induction of ER stress could lead to apoptosis $(7,37)$. Tetrandrine increased the levels of $\Delta \Psi_{m}$ in NPC-TW 039 cells significantly (Figure 4C). It is shown that Tetrandrine-induced apoptosis may not be through dysfunction of mitochondria or decreased levels of $\Delta \Psi_{m}$, so it could be via another cell death pathway. Tetrandrine increased caspase- $8,-9$ and -3 activities in NPCTW 039 cells time-dependently (Figure 5). Based on the observations, we suggest that Tetrandrine induced apoptotic cell death maybe involved with ROS production, ER stress and caspase activation in NPC-TW 039 cells.

In order to further examine whether Tetrandrine-induced cell apoptosis in NPC-TW 039 cells involved apoptotic protein expression, Western blotting experiments showed that Tetrandrine increased the mitochondria-related pathway proteins expression of Bcl-2 and Bcl-x (Figure 6A) but increased pro-apoptotic proteins such as Bax, AIF, Endo G (Figures 6A and $\mathrm{B}$ ). These results show that Tetrandrine induced cell apoptosis in NPC-TW 039 cells, but not through the mitochondria-dependent pathway. This is the major different finding from our previous study in NPC-TW 076 cells. The reason may be that those two cell lines are from different aged patients, and the energy utilization and metabolic abilities are different. Therefore, the mitochondria functions of NPC-TW 076 and NPC-TW 039 cells are quite different.

Furthermore, we found that Tetrandrine increased the activities of caspase-8, -9 and -3 (Figure 5), and we also used western blotting which show that Tetrandrine increased active-caspase-3, -8, -9 and -12 (Figures 6C and D). Anticancer drugs induced caspase-independent apoptotic cell death through AIF and/or Endo G release from mitochondria (39). Results from Figure 6B indicated that Tetrandrine induced the release of AIF and Endo-G release after treatment with NPC-TW 039 cells. Furthermore, Figure 9A and B also showed that Tetrandrine increased ER stress associated protein expression such as GRP78, GADD153 and active forms with Calpain-1 and Calpain-2 in NPC-TW 039 cells (Figure 6D). Some studies have shown that ROS and $\mathrm{Ca}^{2+}$ influx could modulate Calpain protein which is related with apoptosis $(40,41)$. In order to investigate that calcium plays a major role in this study, we chose BAPTA as a calcium chelating agent which blocks the calcium signaling pathway. Figure 7A shows that after BAPTA treatment recovery, cell viability was decreased by Tetrandrine. Calcium concentration was reduced following chelation with BAPTA (Figure 7B). In addition, we found that calcium release blocked by BAPTA could weaken the induction activity of caspase- 3 and -9 after Tetrandrine treatment (Figure 8). Confocal fluorescence microscope is a powerful tool to analyze immunostaining and protein expression, and it clearly demonstrated that BAPTA treatment could weaken the protein expression of GRP78 and GADD153 induced by Tetrandrine treatment (Figure 9 $A$ and $B$ ). Our results indicated that Tetrandrine induced unfolding protein response (UPR) and ER stress-mediated apoptosis in NPC-TW 039 cells via calcium/calpain modulation (Figure 10).

Our findings provided important possible molecular mechanisms of the anti-nasopharyngeal cancer properties of Tetrandrine and support the execution of further investigations to examine its use as a nasopharyngeal cancer drug.

\section{Conflicts of Interest}

The Authors do not have any conflicts of interest to disclose.

\section{Acknowledgements}

This work was supported by the China Medical University [grant numbers CMU105-ASIA-03]; Experiments and data analysis were performed in part through the use of the Medical Research Core Facilities Center, Office of Research \& Development at China medical University, Taichung, Taiwan. 


\section{References}

1 Robinson M, Suh YE, Paleri V, Devlin D, Ayaz B, Pertl L and Thavaraj S: Oncogenic human papillomavirus-associated nasopharyngeal carcinoma: an observational study of correlation with ethnicity, histological subtype and outcome in a UK population. Infect Agent Cancer 8: 30, 2013.

2 Meng LH, Zhang H, Hayward L, Takemura H, Shao RG and Pommier Y: Tetrandrine induces early G1 arrest in human colon carcinoma cells by down-regulating the activity and inducing the degradation of G1-S-specific cyclin-dependent kinases and by inducing p53 and p21Cip1. Cancer Res 64: 9086-9092, 2004.

3 Liu C, Gong K, Mao X and Li W: Tetrandrine induces apoptosis by activating reactive oxygen species and repressing Akt activity in human hepatocellular carcinoma. Int J Cancer 129: 15191531, 2011.

4 Sakurai Y, Kolokoltsov AA, Chen CC, Tidwell MW, Bauta WE, Klugbauer N, Grimm C, Wahl-Schott C, Biel M and Davey RA: Ebola virus. Two-pore channels control Ebola virus host cell entry and are drug targets for disease treatment. Science 347 995-998, 2015.

5 Wang $\mathrm{H}$ and Chen $\mathrm{X}$ : Tetrandrine ameliorates cirrhosis and portal hypertension by inhibiting nitric oxide in cirrhotic rats. J Huazhong Univ Sci Technolog Med Sci 24: 385-388, 395, 2004.

6 Hanahan D and Weinberg RA: Hallmarks of cancer: the next generation. Cell 144: 646-674, 2011.

7 Chu YL, Ho CT, Chung JG, Raghu R, Lo YC and Sheen LY: Allicin induces anti-human liver cancer cells through the p53 gene modulating apoptosis and autophagy. J Agric Food Chem 61: 9839-9848, 2013

8 Chiou SM, Chiu CH, Yang ST, Yang JS, Huang HY, Kuo CL, Chen PY and Chung JG: Danthron triggers ROS and mitochondriamediated apoptotic death in C6 rat glioma cells through caspase cascades, apoptosis-inducing factor and endonuclease $\mathrm{G}$ multiple signaling. Neurochem Res 37: 1790-1800, 2012.

9 Chiu TH, Lan KY, Yang MD, Lin JJ, Hsia TC, Wu CT, Yang JS, Chueh FS and Chung JG: Diallyl sulfide promotes cell-cycle arrest through the $\mathrm{p} 53$ expression and triggers induction of apoptosis via caspase- and mitochondria-dependent signaling pathways in human cervical cancer Ca Ski cells. Nutr Cancer 65: 505-514, 2013.

10 Wu SH, Bau DT, Hsiao YT, Lu KW, Hsia TC, Lien JC, Ko YC, Hsu WH, Yang ST, Huang YP and Chung JG: Bufalin induces apoptosis in vitro and has Antitumor activity against human lung cancer xenografts in vivo. Environ Toxicol 32: 1305-1317, 2017.

11 Bhosale G, Sharpe JA, Sundier SY and Duchen MR: Calcium signaling as a mediator of cell energy demand and a trigger to cell death. Ann N Y Acad Sci 1350: 107-116, 2015.

12 Llorente-Folch I, Rueda CB, Pardo B, Szabadkai G, Duchen MR and Satrustegui J: The regulation of neuronal mitochondrial metabolism by calcium. J Physiol 593: 3447-3462, 2015.

13 Logan CV, Szabadkai G, Sharpe JA, Parry DA, Torelli S, Childs AM, Kriek M, Phadke R, Johnson CA, Roberts NY, Bonthron DT, Pysden KA, Whyte T, Munteanu I, Foley AR, Wheway G, Szymanska K, Natarajan S, Abdelhamed ZA, Morgan JE, Roper H, Santen GW, Niks EH, van der Pol WL, Lindhout D, Raffaello A, De Stefani D, den Dunnen JT, Sun Y, Ginjaar I, Sewry CA, Hurles M, Rizzuto R, Duchen MR, Muntoni F and Sheridan E: Loss-of-function mutations in MICU1 cause a brain and muscle disorder linked to primary alterations in mitochondrial calcium signaling. Nat Genet 46: 188-193, 2014.
14 Mekahli D, Bultynck G, Parys JB, De Smedt H and Missiaen L: Endoplasmic-reticulum calcium depletion and disease. Cold Spring Harb Perspect Biol 3, 2011.

15 Lin YJ, Peng SF, Lin ML, Kuo CL, Lu KW, Liao CL, Ma YS, Chueh FS, Liu KC, Yu FS and Chung JG: Tetrandrine Induces Apoptosis of Human Nasopharyngeal Carcinoma NPC-TW 076 Cells through Reactive Oxygen Species Accompanied by an Endoplasmic Reticulum Stress Signaling Pathway. Molecules 21, 2016.

16 Lin CT, Wong CI, Chan WY, Tzung KW, Ho JK, Hsu MM and Chuang SM: Establishment and characterization of two nasopharyngeal carcinoma cell lines. Lab Invest 62: 713-724, 1990.

17 Liu S-P, Hsu C-Y, Fu R-H, Huang Y-C, Chen S-Y, Lin S-Z and Shyu W-C: Sambucus williamsii induced embryonic stem cells differentiated into neurons. Biomedicine 5: 1-5, 2015.

18 Ip SW, Chu YL, Yu CS, Chen PY, Ho HC, Yang JS, Huang HY, Chueh FS, Lai TY and Chung JG: Bee venom induces apoptosis through intracellular $\mathrm{Ca}^{2+}$-modulated intrinsic death pathway in human bladder cancer cells. Int J Urol 19: 61-70, 2012.

19 Ma YS, Weng SW, Lin MW, Lu CC, Chiang JH, Yang JS, Lai KC, Lin JP, Tang NY, Lin JG and Chung JG: Antitumor effects of emodin on LS1034 human colon cancer cells in vitro and in vivo: roles of apoptotic cell death and LS1034 tumor xenografts model. Food Chem Toxicol 50: 1271-1278, 2012.

20 Huang SH, Wu LW, Huang AC, Yu CC, Lien JC, Huang YP, Yang JS, Yang JH, Hsiao YP, Wood WG, Yu CS and Chung JG: Benzyl isothiocyanate (BITC) induces $\mathrm{G}_{2} / \mathrm{M}$ phase arrest and apoptosis in human melanoma A375.S2 cells through reactive oxygen species (ROS) and both mitochondria-dependent and death receptor-mediated multiple signaling pathways. J Agric Food Chem 60: 665-675, 2012.

21 Chu YL, Ho CT, Chung JG, Rajasekaran R and Sheen LY: Allicin induces p53-mediated autophagy in Hep G2 human liver cancer cells. J Agric Food Chem 60: 8363-8371, 2012.

22 Vermes I, Haanen C, Steffens-Nakken H and Reutelingsperger C: A novel assay for apoptosis. Flow cytometric detection of phosphatidylserine expression on early apoptotic cells using fluorescein labelled Annexin V. J Immunol Methods 184: 39-51, 1995.

23 Kuo JH, Shih TY, Lin JP, Lai KC, Lin ML, Yang MD and Chung JG: Cantharidin induces DNA damage and inhibits DNA repairassociated protein expressions in TSGH8301 human bladder cancer cell. Anticancer Res 35: 795-804, 2015.

24 Shang HS, Shih YL, Lee CH, Hsueh SC, Liu JY, Liao NC, Chen YL, Huang YP, Lu HF and Chung JG: Sulforaphane-induced apoptosis in human leukemia HL-60 cells through extrinsic and intrinsic signal pathways and altering associated genes expression assayed by cDNA microarray. Environ Toxicol 32: 311-328, 2017.

25 Leung YM, Wong KL, Chen SW, Lu DY, Kuo CS, Chen YR, Chen YW and Cheng TH: Down-regulation of voltage-gated $\mathrm{Ca}^{2+}$ channels in $\mathrm{Ca}^{2+}$ store-depleted rat insulinoma RINm5F cells. Biomedicine 3: 130-139, 2013.

26 Shounan Y, Feng X and O'Connell PJ: Apoptosis detection by annexin $\mathrm{V}$ binding: a novel method for the quantitation of cellmediated cytotoxicity. J Immunol Methods 217: 61-70, 1998.

27 Huang WW, Chiu YJ, Fan MJ, Lu HF, Yeh HF, Li KH, Chen PY, Chung JG and Yang JS: Kaempferol induced apoptosis via endoplasmic reticulum stress and mitochondria-dependent pathway in human osteosarcoma U-2 OS cells. Mol Nutr Food Res 54: 1585-1595, 2010. 
28 Lee HZ, Liu WZ, Hsieh WT, Tang FY, Chung JG and Leung HW: Oxidative stress involvement in Physalis angulata-induced apoptosis in human oral cancer cells. Food Chem Toxicol 47: 561-570, 2009.

29 Lin Y-J, Ho T-J, Lin T-H, Hsu W-Y, Huang S-M, Liao C-C, Lai C-H, Liu X, Tsang H, Lai C-C and Tsai F-J: P-coumaric acid regulates exon 12 splicing of the ATP7B gene by modulating hnRNP A1 protein expressions. Biomedicine 5: 1-9, 2015.

30 Chang ET and Adami HO: The enigmatic epidemiology of nasopharyngeal carcinoma. Cancer Epidemiol Biomarkers Prev 15: 1765-1777, 2006.

31 He ZM, Wang SL, Yuan JH and Chen ZC: Expression of human cytochrome P450 2E1 gene in embryonic nasopharynx, nasopharyngeal cancer cell lines and tissue. Ai Zheng 21: 597600, 2002.

32 Qin R, Shen H, Cao Y, Fang Y, Li H, Chen Q and Xu W: Tetrandrine induces mitochondria-mediated apoptosis in human gastric cancer BGC-823 cells. PLoS One 8: e76486, 2013.

33 Sun X, Xu R, Deng Y, Cheng H, Ma J, Ji J and Zhou Y: Effects of tetrandrine on apoptosis and radiosensitivity of nasopharyngeal carcinoma cell line CNE. Acta Biochim Biophys Sin (Shanghai) 39: 869-878, 2007.

34 Gao JL, Ji X, He TC, Zhang Q, He K, Zhao Y, Chen SH and Lv GY: Tetrandrine Suppresses Cancer Angiogenesis and Metastasis in 4T1 Tumor Bearing Mice. Evid Based Complement Alternat Med 2013: 265061, 2013.

35 Ma H, Yao L, Pang L, Li X and Yao Q: Tetrandrine ameliorates sevofluraneinduced cognitive impairment via the suppression of inflammation and apoptosis in aged rats. Mol Med Rep 13: 4814-4820, 2016
36 Liu KC, Shih TY, Kuo CL, Ma YS, Yang JL, Wu PP, Huang YP, Lai KC and Chung JG: Sulforaphane Induces Cell Death Through $\mathrm{G}_{2} / \mathrm{M}$ Phase Arrest and Triggers Apoptosis in HCT 116 Human Colon Cancer Cells. Am J Chin Med 44: 1289-1310, 2016.

37 He G, He G, Zhou R, Pi Z, Zhu T, Jiang L and Xie Y: Enhancement of cisplatin-induced colon cancer cells apoptosis by shikonin, a natural inducer of ROS in vitro and in vivo. Biochem Biophys Res Commun 469: 1075-1082, 2016.

38 Lai CI, Chu YL, Ho CT, Su YC, Kuo YH and Sheen LY: Antcin $\mathrm{K}$, an active triterpenoid from the fruiting bodies of basswood cultivated Antrodia cinnamomea, induces mitochondria and endoplasmic reticulum stress-mediated apoptosis in human hepatoma cells. J Tradit Complement Med 6: 48-56, 2016.

39 Hsiao YP, Yu CS, Yu CC, Yang JS, Chiang JH, Lu CC, Huang HY, Tang NY, Yang JH, Huang AC and Chung JG: Triggering apoptotic death of human malignant melanoma a375.s2 cells by bufalin: involvement of caspase cascade-dependent and independent mitochondrial signaling pathways. Evid Based Complement Alternat Med 2012: 591241, 2012.

40 Cui W, Ma J, Wang X, Yang W, Zhang J and Ji Q: Free fatty acid induces endoplasmic reticulum stress and apoptosis of betacells by $\mathrm{Ca}^{2+/ c a l p a i n-2}$ pathways. PLoS One 8: e59921, 2013.

41 Ray SK, Fidan M, Nowak MW, Wilford GG, Hogan EL and Banik NL: Oxidative stress and $\mathrm{Ca}^{2+}$ influx upregulate calpain and induce apoptosis in PC12 cells. Brain Res 852: 326-334, 2000.

Received June 19, 2017

Revised July 19, 2017

Accepted July 26, 2017 